\title{
Emerging Perspectives on Post-Conflict Police-Community Relations
}

\author{
Ingrid L. P. Nyborg \\ Department of International Environment and Development Studies, Norwegian University of Life Sciences (NMBU), Ås, \\ Norway. E-Mail: ingrid.nyborg@nmbu.no
}

Published: 30 May 2019

The world is increasingly interconnected-insecurity in one country can both directly and indirectly affect the security of people, countries and regions that are far away. Therefore, when conflict erupts in one part of the world, the international community responds in various ways to mitigate its effects, both locally and internationally. Whether it be through the provision of police, military and/or civilian personnel, humanitarian assistance, or post-conflict development assistance, the international community has repeatedly attempted to mitigate the effects of conflict, as well as to contribute to reforms which might lead to the prevention of local and global insecurity in the future.

To achieve these broad goals of prevention, the international community has invested heavily in security sector reform (SSR). While much of the focus of these efforts remains on peacekeeping and military support, there has been a growing interest in supporting longer-term police reform processes in post-conflict contexts as a way to strengthen rule of law and contribute to democratic institution-building. Despite decades of experience with international support to police reform the evaluations of these missions have, however, pointed to serious problems in the ways in which police reform assistance has been implemented. Several high-level reports and research papers have, for example, pointed to the increased militarization of the police, and the lack of local ownership of police reform processes [1]. Specifically, the policing approaches chosen for post-conflict settings have not been able to establish democratic, accountable policing institutions that effectively protect the population from violence and human rights abuses. Nor have they been able to contribute to the building of trust between the police and the population to ensure that people feel safe and that their rights are ensured. What has gone wrong? Is a paradigm shift in policing necessary in these contexts?

This Special Issue is dedicated to exploring communityoriented policing (COP) and police reform in a series of post-conflict contexts: Afghanistan, Pakistan, Kenya, Nicaragua and El Salvador. The papers are based on mixed-methods research conducted under the EU-funded project 'Community-Oriented Policing and Post-Conflict Police Reform' (ICT4COP 2015-2020) [2]. In this project we explore how police reform in volatile contexts has taken place, and whether a focus on COP approaches rather than militarized approaches might be more effective in building trust, preventing violence and ensuring human security. We also explore some of the ways in which information and communications technology (ICT) might contribute to improving communication and trust between the police and communities in these challenging contexts [3]. In order to discover new insight into these issues, the research has been empirically informed, interdisciplinary and qualitative, as well as co-produced through the inclusion of police, civil society organizations and local women and men in the discussion of research results from its inception. This has provided an innovative take on understanding post-conflict policing, one which suggests the need to think anew some of our basic understandings and assumptions about conflict, security, policing, reform and technology.

\section{Post-Conflict}

'Conflict' is a broad term that can range from low-level conflicts between individuals, to larger conflicts at sub-national 
or regional levels. In our research, the use of the term postconflict refers to the period following an intense, violent conflict, and where there has been a particularly focused response nationally and/or internationally to improve relations between the government and its citizens, or within society in general, through peace building, development and SSR. The cases included in the project and this special issue have all experienced such larger conflicts, but the nature of conflict has of course been qualitatively different in each historical context. For example, in Nicaragua there was a socialist revolution (1978-1979) and civil war (1981-1990), in Afghanistan there was first an occupation by the USSR, and then a civil war (1979-2001), El Salvador experienced a devastating civil war (1979-1992), in Kenya there has been decades of ethnic violence and recent terrorist attacks, and in Pakistan there was an armed conflict in the Swat Valley (2009) and unrest in the border areas with Afghanistan. Common to all the cases is the need to rebuild trust when armed conflict has ceased, between the government and the population, and between different sectors of the populations. However, it is important to note that despite the passing of a formal political peace process, violent conflict never completely ended in any of these cases [4]. Conflict persists at several levels-pre-existing conflicts have resurfaced, new conflicts have emerged, and violence can be extreme. In one sense, conflict can be considered as a part of everyday life, and, therefore, something that cannot be ended completely, but its violent forms can be minimized. How conflict is understood will influence how states, donors, and local communities work to rebuild or transform their societies. For this research, we have chosen case studies at different stages of conflict and reform, including those which are currently experiencing a resurgence of major conflict, such as Afghanistan.

\section{Human Security and the Security-Development Nexus}

Perhaps the most central concept framing our research is human security. Our choice of human security as a framework is critically anchored in wider debates on security and development in which issues of state building, peacebuilding, post-conflict violence, SSR and COP are tightly embedded. Intensified interest in the relationship between security and development, and the growing recognition of their close interlinkage, led to the emergence of new thinking around security and development in the post-9/11 era of terrorism and the rise of global threats [5]. A growing recognition of the failure of conventional security approaches to provide the necessary conditions for sustainable development in critical contexts followed. This has resulted in the emergence of new perspectives on the linkage between security and development. Security and development were, for example, increasingly conceptualized as mutually reinforcing and a central link in transitions from conflict to recovery [6]. Subsequently, development policies favored greater integration of security matters while the scope of security policies moved to integrate development issues as well [7] In practice, this resulted in the piloting of new constellations of collaboration between the security and development sector, some of which have been highly criticized due to the uneven influence of national and international security interests over development principles in post-conflict contexts where the military is in the driver's seat of reconstruction policy [8]. This was particularly problematic due to the clear focus on military perspectives of security of the state and goals of stability in SSR.

Despite the more recent inclusion of civilian dimensions in international SSR policy [9], practice continues to reflect a focus primarily on state security. Such an approach, however, has at least two serious limitations. First, an uncritical focus on strengthening state security can result in perverse outcomes such as international support for repressive regimes and elites. Second, this perspective limits our understanding of how people experience insecurities which fall outside of this conceptualization, but are nevertheless experienced and perceived as very real threats to their lives and well-being. This could include, for example, threats to health, livelihoods and resources, which may be either directly or indirectly connected to a conflict, but in ways that may not be so apparent from a military perspective. This can result in a police force trained in military tactics and as a paramilitary force, rather than as a service to protect the broader rights and interests of the population [10]. For example, it is possible to observe this in the case of Afghanistan where police at one point were trained by the military to increase the 'boots on the ground' needed to face the threat of insurgents, at the expense of training in regular policing skills (Nyborg, Ganapathy and Nimruzi, this issue) [11].

While the debates around the security-development nexus provided a critical view of two competing worldviews on local and global relations, they did not offer much in terms of an analytical perspective that could bridge these two worlds in a constructive and innovative way. This is where human security was seen to fill the gap. The term was originally coined in 1994 by the UN as freedom from want, and freedom from fear, and expanded in 2003 to include freedom to live in dignity. While much of the early focus on human security was on finding a definition and listing of what types of insecurities comprise human security [12], the emphasis has shifted to an understanding of human security in broader, processual terms. Gasper [13], for example, examines human security with respect to whose security, security of what, to what extent, and against what threats, and its purpose. In doing so, he identifies a range of definitions, which comprise different human security discourses depending on the purpose and needs of the actors. Some of these definitions are narrow, for example as a security or interventionist policy [14], while others are rather broad, encompassing all of human development [15]. Common to many, and important for our research, is a focus on people rather than the state as the object of insecurity, a move beyond physical violence as the only threat, the interconnectedness of threats, and an understanding of hu- 
mans as more than individuals but part of a social, political context, and as both vulnerable and capable [16]. Human security in this sense is both broadened in terms of what constitutes a threat and narrowed to focus on contextual and normative priorities [13].

The implications of choosing a human security approach for our research are many. Analytically, a human security discourse provides us with an intellectual bridge between disciplines, sectors and stakeholders. In doing so, it has enabled researchers, policymakers, and practitioners within security, development, policing, technology, political science and anthropology to engage with each other and directly with local women and men to understand and address the complexities inherent in a variety of post conflict contexts. A focus on human security has, thus, had significant implications for our methodologies. We investigate, for example, the ways in which different people define their own experiences of threats to their well-being. To access this information we have employed a qualitative, narrative, anthropological and co-productive methodology in our field studies. We have a strong focus on exploring the contextuality of insecurity. This has required us to pay attention to historical, social and political understandings of conflict and reform processes in each case. We do not only consider vulnerabilities and issues of protection, but capabilities and issues of empowerment i.e. consider how people work to secure their lives in light of conflict and insecurities, individually, collectively and through local state and non-state institutions. We consider the interconnectedness of insecurities in a particular context. We study how these interact in each case to result in a particular constellation of roles, responsibilities and outcomes that are relevant for understanding human security. This allows us, for example, to not only critically analyze how police perform their duties in these challenging contexts, but their role in relation to other state and non-state institutions, and to civil society, in addressing and preventing insecurities. Again, this often has different features in each of the cases, as they represent particular histories and institutional constellations.

An important dimension of our use of human security is our focus on the social foundations of power relations, and how they influence the ways in which police reform is both implemented and practiced. We consider, for example, how unequal power relations between the international community (military and police advisors) and local, relatively weak post-conflict governments influence the way in which community policing is designed and implemented both nationally and locally [17]. This power imbalance has sparked concern that the international community has introduced COP and that it represents Western philosophy and policing strategy that is irrelevant to different settings abroad [17]. The role of the international community in COP implementation is discussed in the articles on Afghanistan (Nyborg, Ganapathy and Nimruzi, this issue; Coyne and Nyborg, this issue) [18], and in the practitioner article on police expert networks (Ganapathy, Damkås and Naesje, this issue) [19]. Likewise, power relations within and be- tween national government actors, non-government actors, security actors, civil society and local communities are also examined, including issues of gendered relations and the position of vulnerable groups. The inclusion of power relations enables a more critical and complex analysis of the possibilities and limitations faced in police reform that go beyond an instrumental understanding of challenges in terms of lack of resources and training.

\section{Community-Oriented Policing (COP)}

Since the 1990s, research on COP has produced an extensive array of literature spread across disciplines, from police science and criminology to state building, peacekeeping and development studies [20], and including seminal studies pointing to major analytical and empirical challenges [20]. Numerous studies in this literature have focused on Western models of COP. Some of these studies have sought to share guidelines for the wider development of 'democratic policing' [21]. More recently, some studies have in contrast sought to explore the diversity of international patterns in COP and emerging experiences of COP in post-conflict contexts [22].

While contributing in different ways to our understanding of COP in post-conflict contexts, most of these studies have focused on administrative and territorial questions, as well as the activities of international actors and the specific interests of donors in COP. The people themselves, the changes that they have lived through both during and after decades of conflict, and their relation to governmental law enforcement agencies like the police, have not been addressed. Research and analysis has thus largely ignored people and their engagement in police reform and democratization processes [23]. We therefore suggest that the thinking and practice of COP could benefit from an in-depth qualitative understanding and integration of local experiences [24].

Despite the increasing attention to COP in the UN and EU, it remains the subject of definitional debates and interpretations by various actors involved in policing activities. This lack of a common, clear definition has on the one hand led to confusion about both what constitutes its approach and activities, as well as how one might measure its utility and effectiveness [25]. On the other hand, this same lack of a common definition can be said to have led to the development of a diverse set of policing systems in very different local contexts claiming to be COP, but with very different content and impact. In our research we ask what we can learn from this diversity. We ask whether there are ways of understanding trust-building, accountability, governmentcivil society relationships that are contextually specific, but can nevertheless inform an understanding of COP on a broader level. Indeed, we are concerned to learn if this might provide some new insight that can be used to improve reform processes and contribute to improved human security for all.

There is broad agreement that without community involvement and support, police reform efforts have little 
chance to prove successful [26]. COP is now widely recognized as a relevant approach to policing and restoring trust in police/community relations. Whilst COP is now widely recognized as a strategic aspect of police assistance programs, its relation, connecting and paralleling of conventional approaches to police reform need to be studied more closely. The institutional reform of the police in post-conflict settings has often involved support to, for example, institutional restructuring, establishment of and improvements in police training and education systems, human capacity building in both operations and strategy development, and upgrading of equipment. The focus has often been on improving police efficiency and effectiveness in maintaining the rule of law and can also involve links to reforms of the judiciary and prison sectors. In the aftermath of armed conflict, however, police-community relations and trust levels in society in general are typically very low. In our project we have tried to identify how police reform processes can contribute to greater cooperation between law enforcement agencies and citizens in post-conflict contexts. In some cases this dynamic is complicated by histories in which citizens may have recently been the victims of abuse by the same law enforcement agencies before, during and post-conflict.

Despite some consistency at a policy level, there are many approaches to COP, and each model can have very different sets of activities, goals and expectations. Some focus on the way COP might contribute to police effectiveness in terms of quality, responsiveness and accountability of police services. Others focus on engaging with communities for community-based solutions to local issues [27]. They can aim to re-establish the broken links between communities and police, establish them where they may never have existed, or re-negotiate them where they were poor in the past. They may aim to change public perceptions of the police, and rehabilitate the police institution in a way that encourages citizens to trust, interact and support their police in preventing, reporting and fighting crime and terrorism. The increased attention to COP in police reform in police missions abroad, however, has proved challenging. International police advisors often experience frustration in their missions, and typically report a lack of adequate knowledge on COP and the specific contexts in which they conduct their assignments [28]. They often rely on their national understanding of COP, even when working on developing 'locally owned' forms of COP for the country where they are posted. They can as well face ethical dilemmas when local institutions seem at odds with international human rights. Likewise, national actors may feel that COP is a Western approach to policing that is imposed upon them. They may experience a lack of consideration of and respect for existing traditional conflict resolution and justice institutions and mechanisms when COP is being designed and implemented. The tensions arising at the interface of international, government and traditional institutions is a recurring theme in several of our research cases. Rather than fall into an essentialist, binary discussion of what such relations and roles should be, our cases attempt to unravel the complexities and dilemmas inherent in these interfaces. The article on police reform in Pakistan, for example, explores how new legal police frameworks link with traditional institutions of conflict resolution, and what this means in terms of building trust between communities and the government, and the perpetuation of unequal gender relations. The articles on Afghanistan explore the diverse ways of engaging civil society in COP, and the challenges and advantages of linking with traditional security institutions. These cases demonstrate that we need a more nuanced understanding of these relationships in order to move beyond a view of local institutions as always a problem, and international assistance as always an imposition.

There is need for a discussion regarding the institutionalization and sustainability of COP. When international actors depart and national actors take over, COP activities may continue as planned, be discontinued, or change into something quite different. While some would see the last two as failures, they could in fact represent adaption to actual local needs [29]. On the other hand, if COP continues, is it a clear sign of its institutionalization and sustainability? The article on EI Salvador argues that despite a well-developed policy for COP at national level, and its inclusion in police training, its implementation on the ground is minimal, and the police continue to use force and repression to fight crime. The evidence suggests that this is in part due to the dominance of a masculinist construction of security that deem COP as less masculine (Rojas, this issue) [30]. The article on Afghanistan, on the other hand, describes how despite the decreasing international SSR funding, the Afghan National Police developed their own COP [31] policy, included COP in the Mol institutional structure, incorporated COP into its regular curriculum and expanded COP into almost all of its provinces Nyborg, Ganapathy and Nimruzi, this issue) [32]. The article on Nicaragua describes the development of a post-revolutionary police force that was proactive, communitarian and preventative (McNeish, Prado, and Frühling, this issue) [33]. This COP model was long considered a success story in that it avoided the levels of crime and insecurity apparent elsewhere in the region. An authoritarian shift in the government in 2018, however, has led to political unrest and violence, and a more centralized policing system, undermining COP. These cases illustrate that institutionalization and sustainability of COP are not only a function of how well a program is designed, but are influenced by wider social relations and political processes often outside of the control of the policing system.

\section{COP and Technology}

In addition to contextual aspects of policing systems, there are major gaps in the literature regarding the use of technology for COP and its ability to facilitate cooperation between police and citizens in these difficult contexts. As information and communication technologies (ICT) are rapidly developing and spreading, their use by police is increasingly discussed, also in the case of police assistance 
missions abroad. Most of the focus has been in using ICT to improve police efficiency, surveillance and crime reporting. Much less focus has been on how to use ICT in COP to improve communications and build trust between the police and communities. In our project we have attempted to identify what possibilities and limitations exist for the use of ICT for COP Given the difficult contexts of intervention and the increased sensitivity of data integrity issues associated with the use of technologies in such contexts, the use of ICT remains a challenge. A key question we have asked in our work is: How do we ensure that ICT for COP is not co-opted for increased surveillance and the creation of a police state?

The South Asian paper considers the different types of technologies used in policing in the region, and suggests that there is a potential for expanding the range of ICTs to go beyond their use for efficiency and surveillance, to contribute to trust-building (Maqsood, Madani, Nawab, Ullah and Nyborg, this issue) [34]. While this is a relatively new area for policing, the use of ICTs for development began in the 1950s. The field of ICT for Development (ICT4D) can therefore provide useful experience around the contribution of technology to social, economic and environmental development. Mobile technology, for example, has been used to facilitate service delivery when other types of traditional infrastructure are lacking [35]. ICT4D scholars have also developed frameworks for ethical aspects [36] and for identifying risks and challenges in the use of ICT for development that might inform discussions of ICT for COP [37].

The challenges for ICT for COP are similar for those for ICT4D, including access and availability of technology infrastructure, privacy and security issues and the design of effective and affordable feedback loops, ICT capacity building for public sector actors, the strategic use of already available technologies, the integration of global and local experiences, and monitoring and evaluation [38]. Particularly challenging for ICT in both development and COP is the use of bottom-up approaches such as participatory technology development [39]. In policing, technology development is typically top-down and controlled by the police, who may neither trust the population, nor enjoy their trust. There is also a tendency to believe that technical solutions alone can replace the need for face-to-face communication. Evidence from our research suggests that is not so, particularly in contexts with trust deficits. Before recent events, the Nicaraguan model had been successful largely on the basis of its human and not technological interface (McNeish, Prado and Frühling, this issue) [40]. Technologies are likely only a small part of a trust-building process, the nature of which is dependent on the context. The way a government, and particularly the police, uses technology may in fact be an indicator of how they view their relationship with civil society. In Pakistan, improving the image of the police and their relationship with communities is promoted at both national and provincial levels, but at the same time, the government has intensified its control of social media con- tent and the use of online surveillance technology (Nawab, Ullah, Nyborg and Maqsood, this issue) [41].

\section{Government-Civil Society Relations}

While it may seem that COP is merely the performance of a series of consultations, dialogue, and joint activities through the use of good communication skills, the policing approach touches on the very essence of how governments relate to their populations. The introduction of COP in Afghanistan had a strong focus on giving civil society a much clearer role in these relations (Nyborg, Ganapathy and Nimruzi, this issue) [42]. Tensions may, however, arise within governments when some actors push a democratic agenda of local participation and trust-building, while others are intent on using COP to secure control over territory and populations through surveillance and intelligence. The paper on Kenya looks at how COP models are tied to politics and power structures, with one side toting democratization and the other a centralized security agenda (Lid and Okwany, this issue) [43]. In both Afghanistan and Pakistan, the idea of Community Policing, or the use of local informants as sources of intelligence, is strongly engrained in police culture, making it difficult to transition to what is now referred to as Community-Oriented Policing (COP). The paper on Pakistan discusses how recent police reforms try to avoid this terminology altogether, and focus on the use of local terms to describe how the police and the communities communicate and build trust (Nawab, Ullah, Nyborg and Maqsood, this issue) [44].

The papers in this special issue offer insight into how community-oriented policing is practiced and understood in each specific context. They also illustrate the emergence of several common themes that need to be addressed when attempting to understand COP in post-conflict contexts. These include the following: the significance of political, social and gendered power relations at international, national and local levels; continued tensions within the police/government and between the need for surveillance and control and the provision of services to communities, limited understanding of the role of civil society and local institutions in COP, limited awareness of the potentials and dangers of the use of ICTs in these contexts, and the challenges of trust-building in societies where trust both between the police/government and society, and within society itself after conflict are clearly in a deficit. In subsequent publication and research we will continue to address and further develop these insights.

\section{Acknowledgements}

I would like to express my thanks to Kari M. Osland, Norwegian Institute of International Affairs (NUPI) and John A. McNeish, Department of International Environment and Development Studies, Norwegian University of Life Sciences (NMBU) for their comments and contributions to this paper. 


\section{References and Notes}

[1] Bayley D, Perito R. The Police in War: Fighting Insurgency, Terrorism and Violent Crime. Lynne Rienner; 2010. United Nations. Report of the High-level Independent Panel on Peace Operations (HIPPO) on uniting our strengths for peace: Politics, partnership and people; 2015.

[2] The research cases include Afghanistan, Pakistan, Kenya, Somalia/Somaliland, Uganda, Nicaragua, Guatemala, El Salvador, BosniaHerzegovina, Serbia and Kosovo.

[3] See communitypolicing.eu for more information on the project.

[4] Suhrke A. The peace in between: Post-War Violence and Peacebuilding. In: Suhrke A, Berdal M, editors. London: Routledge; 2013.

[5] Stepputat F. Are We in This Together? Security, Development and the 'Comprehensive Approach' Agenda. In: McNeish J, Sander Lie $\mathrm{JH}$, editors. Security and Development. New York: Berghahn; 2010.

[6] Elhawary S, et al. Development, Security \& Transitions in Fragile States. ODI; 2010.

[7] Stewart F. Development and security. Conflict, Security \& Development. 2004;4(3):261-288. doi:10.1080/1467880042000319863.

[8] Nyborg I. When Local Meets Global - Negotiating Rural Livelihoods in the Face of Multiple Security and Development Discourses and Approaches in Afghanistan. In: Kjosavik D, Vedeld P, editors. The Political Economy of Environment and Development in a Globalised World - Exploring the Frontiers. Trondheim: Tapir Academic Press; 2011.

[9] OECD-DAC. Handbook on Security System Reform (SSR): Supporting Security and Justice. Paris: OECD; 2007.; EU Joint Communication to the European Parliament and the Council: Elements for an EU-wide strategic framework to support security sector reform. Strasbourg: UN; 2014. UN Security Council Resolution 2151; 2016.

[10] Osland KM. UN Policing: The Security-Trust Challenge. In: de Coning C, Peter M, editors. United Nations Peace Operations in a Changing Global Order. Springer International Publishing; 2018. pp. 191209. doi:10.1007/978-3-319-99106-1_10.

[11] Nyborg I, Ganapathy J, Nimruzi A. From Guns to Roses: Understanding Community-Oriented Policing in Afghanistan. Journal of Human Security; in revision.

[12] The original list of the seven major areas of human security, for example, was economic security, food security, health security, environmental security, personal physical security, security of community life, and political security (UN 1994).

[13] Gasper D. Human security: from definitions to investigating a discourse. Routledge; 2013.

[14] McCormack T. Power and agency in the human security framework. Cambridge Review of International Affairs. 2008;21(1):113-128. doi:10.1080/09557570701828618.

[15] Haq M. Reflections on Human Development. 2nd ed. Oxford University Press; 1999.

[16] O'Brien K, Barnett J. Global Environmental Change and Human Security. Annual Review of Environment and Resources. 2013;38(1):373391. doi:10.1146/annurev-environ-032112-100655.

[17] Divon S. Police Reform and Power in Post Conflict Societies-A Conceptual Map for Analysis. European Journal of Policing Studies. 2016;4(3):269-298.

[18] Nyborg I, Ganapathy J, A N. From Guns to Roses: Understanding Community-Oriented Policing in Afghanistan;

[19] Ganapathy J, Damkås T, Naesje A. A Bird's Eye View from the Field - Is a Police Experts Network (PEN) the missing link in facilitating sustainable community-oriented policing in post-conflict contexts? Journal of Human Security; in revision.

[20] Dölling D, Feltes T. Community Policing: Comparative Aspects of Community Oriented Police Work; 1993. 10.15496/publikation19608.

[21] Bayley D. Democratizing the Police Abroad: What to Do and How to Do It. Washington, DC, USA: US Department of Justice; 2001.

[22] Wisler D, Onwudiwe I. Community Policing: International Patterns and Comparative Perspectives. Boca Raton, FL, USA: CRC Press; 2009.

[23] O'Neill W. Police Reform in Post-Conflict Societies: What We Know and What We Still Need to Know. The Security Development Nexus Program. New York: International Peace Academy; 2005.

[24] Brogden M. "Horses for Courses" and "Thin Blue Lines": Community Policing in Transitional Society. Police Quarterly. 2005;8(1):64-98. doi:10.1177/1098611104267328.

[25] Brogden M, Nijhar P. Community Policing: National \& International Models and Approaches. Cullompton, UK: Willan Publishing; 2005.

[26] DH B. Democratizing the Police Abroad: What to Do and How to Do It. Washington, DC, USA: US Department of Justice; 2001.

[27] Good Practices on Community Engagement and CommunityOriented Policing as Tools to Counter Violent Extremism. Global Counterterrorism Forum; 2009. Available from: https://www.thegctf. org/documents/10162/159885/13Aug09_EN_Good+Practices+on+ Community+Engagement+and+Community-Oriented+Policing.pdf.

[28] Nyborg I, Ganapathy J. Introducing the Issues: Human Security, Development and the Civil Police in Afghanistan. Workshop Report for 'The Norwegian Police Engagement in Afghanistan: Perspectives on security and development for local women and men'. Noragric, UMB, Police University College, Ministry of Foreign Affairs (Refleks); 2012.

[29] Wassel T. Institutionalizing Community Policing in Timor-Leste. London, UK: ODI; 2014.

[30] Rojas E. Between a rock and a hard place: Community-Oriented Policing and the Gendered Nature of Security in El Salvador. Journal of Human Security; in revision.

[31] Police-e Mardume (PEM).

[32] Nyborg I, Ganapathy J, Nimruzi A. From Guns to Roses: Understanding Community-Oriented Policing in Afghanistan. Journal of Human Security; in revision.

[33] McNeish J, Prado S, Frühling H. Community-Based Policing in Nicaragua: Do the claims of Communitarian, Proactive and Preventative hold true? Journal of Human Security. accepted;

[34] Maqsood T, Madani S, Nawab B, Ullah S, Nyborg I. The Role of ICT in Community-Oriented Policing in South Asia: Challenges and Opportunities. Journal of Human Security; accepted.

[35] GSMA. Scaling Mobile for Development. London, UK: GSMA; 2013.

[36] Dearden A. See no evil? In: Proceedings of the Fifth International Conference on Information and Communication Technologies and Development - ICTD'12. ACM Press; 2012. 10.1145/2160673.2160680.

[37] $\mathrm{J} \mathrm{K}$, et al. dentification Tool for ICT in International Development Cooperation Projects. EJISDC. 2012;55(3):1-26.

[38] SPIDER. Building Participatory Democracy through ICT. Background Paper for Stockholm Internet Forum; 2013.

[39] Banks K. Reflections on a Decade of Mobiles in Development. Stability: International Journal of Security \& Development. 2013;2(3):1-5.

[40] McNeish J, Prado S, Frühling H. Community-Based Policing in Nicaragua: Do the claims of Communitarian, Proactive and Preventative hold true? Journal of Human Security; in revision.

[41] Nawab B, Ullah S, Nyborg I, Maqsood T. Community-Oriented Policing: Political, Institutional and Technical Reforms in Khyber Pakhtunkhwa (KP) Police;. Maqsood T, Madani SA, Nawab B, Ullah S, Nyborg I. The Role of ICT in Community-Oriented Policing in South Asia: Challenges and Opportunities.

[42] Nyborg I, Ganapathy J, A N. From Guns to Roses: Understanding Community-Oriented Policing in Afghanistan;. Coyne AH, Nyborg I. Pushing on a String? An argument for civil society-driven community policing as alternative to ministry-centric approach in conflict-affected states.

[43] Lid S, Okwany C. Protecting citizens or an instrument for surveillance? The development of community policing models in Kenya. Journal of Human Security; in revision.

[44] Nawab B, Ullah S, Nyborg I, Maqsood T. Community-Oriented Policing: Political, Institutional and Technical Reforms in Khyber Pakhtunkhwa (KP) Police. Journal of Human Security; in revision. 